\title{
NOTE
}

\section{Branchial osteogenetic neoplasm in barbel Barbus barbus plebejus}

\author{
Maurizio Manera', Sergio Biavati ${ }^{2}$ \\ ${ }^{1}$ Dipartimento di Scienze Veterinarie e Agroalimentari. Sezione di Patologia Generale e Anatomia Patologica Veterinaria, \\ Facoltà di Medicina Veterinaria, Università degli Studi di Teramo, Località Piano d'Accio, 64020 Nepezzano (TE), Italy \\ ${ }^{2}$ Dipartimento di Sanità Pubblica Veterinaria e Patologia Animale, Sezione di Patologia Generale e Anatomia Patologica, \\ Facoltà di Medicina Veterinaria, Università degli Studi di Bologna, Via Tolara di Sopra, 50, 40064 Ozzano Emilia (BO), Italy
}

\begin{abstract}
A branchial osteogenetic neoplasm affecting a barbel Barbus barbus plebejus (Valenciennes, 1829) is described. The osteoblasts' pleomorphism, the lack of a welldeveloped and complete separation, the presence of eccentric, terminal proliferative edges infiltrating the lining tissues and the abundant tumour matrix suggest a histopathological diagnosis of a 'productive osteoblastic osteosarcoma' The occurrence of eosinophilic granule cells (EGCs) scattered among neoplastic tissue is discussed in relation to the neoplastic growth and the inflammatory reaction, with reference to recent discoveries in mammalian mast cell biology
\end{abstract}

KEY WORDS: Barbel - Barbus barbus plebejus - Gills - Neoplasm - Osteoblastic osteosarcoma Eosinophilic granule cells . EGCs

An emaciated barbel Barbus barbus plebejus (Valenciennes, 1829) measuring approximately $40 \mathrm{~cm}$ in length was caught in the Adige River (North Italy). The fish exhibited a partial opening of the left branchial operculum and when the branchial chamber was dissected, an irregularly shaped, almond-sized tissue mass of reddish-grey color was found on the fourth gill arch. Necropsy performed on the entire fish indicated no gross pathology apart from serious cachexia. The affected gill arch and other tissue samples were preserved in $10 \%$ buffered formalin for later laboratory examination.

The tissue mass appeared to originate at the rostral edge of the gill arch; however, the osteo-chondroid axis of gill arch was not part of the tumour. Greyishreddish ulcerations of the superficial pharyngeal mucous-epithelium were evident and a trabecular mass of bony appearance could be detected. Subsequent-dissection of the tumour proved difficult because an osteo-chondroid consistency made the tumour resistant to cutting, prompting us to decalcify the tissue mass with an EDTA-based calcium chelating agent. Following decalcification, the tumour was sectioned with the sectioning plane oriented perpendicular to the gill arch. Tissue sections were processed for light microscopy and stained using the following techniques: Haematoxylin \& Eosin, Alcian-Pas (McManus \& Mowry 1960), Gomori Trichromic Stain (Mazzi 1977), Von Kossa (Pearse 1985).

Histologically, 3 tissue areas could be identified:

(1) The core of the mass appeared to be composed primarily of trabecular, lamellar bone forming a reticule which lined loose, well-vascularised fibro-connective tissue and displayed proliferative, osteogenetic edges (Fig. 1)

(2) The proliferative edges of the osseous core merged gradually into a region of inflammatory fibrohistiocytic tissue. A shape progression from osteoblasts to fibroblastic-like cells was observed. Abundance of eosinophilic granule cells (EGCs) could also be seen in that tissue.

(3) The osseous, fibro-connective mass was superficially lined by the pharyngeal mucous-epithelium, displaying erosions, ulceration and mucous-epithelial cysts in the underlying connective tissue (propria-submucosa) (Fig. 2). Several EGCs were evident in the epithelium and in the propria-submucosa (Fig. 3).

Histologically, the trabecular osseous tissue had a lamellar appearance and was lined by pleomorphic osteoblasts. Laterally, the cells appeared flattened and fibroblast-shaped; at the proliferative edges, the cells were arranged in a palisade formation with the major axis oriented perpendicular to the osteoid spicule (Figs. 4 \& 5). Osteoblasts characteristically displayed basophile cytoplasm and contained large nuclei that were rich in euchromatin and had prominent nucleoli, 


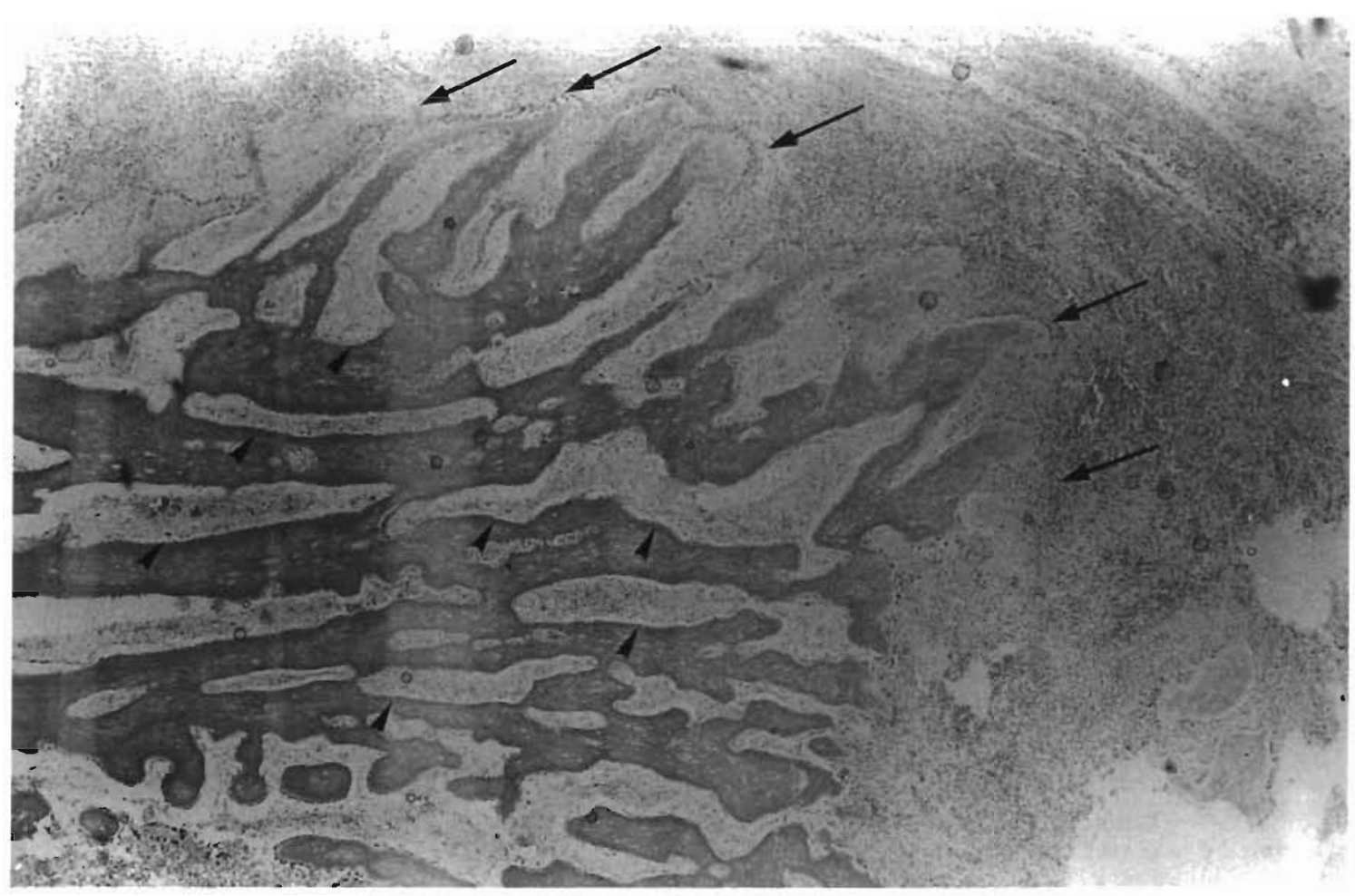

Fig. 1. Barbel, fourth gill arch, tumorous mass. A trabecular bone reticule, defining regions of loose, well-vascularised fibroconnective tissue (arrowheads), is apparent. Proliferative edges are evident (arrows), eliciting a fibro-histiocytic reaction (on the right). Haematoxylin \& Eosin. Decalcified tissue. $\times 40$

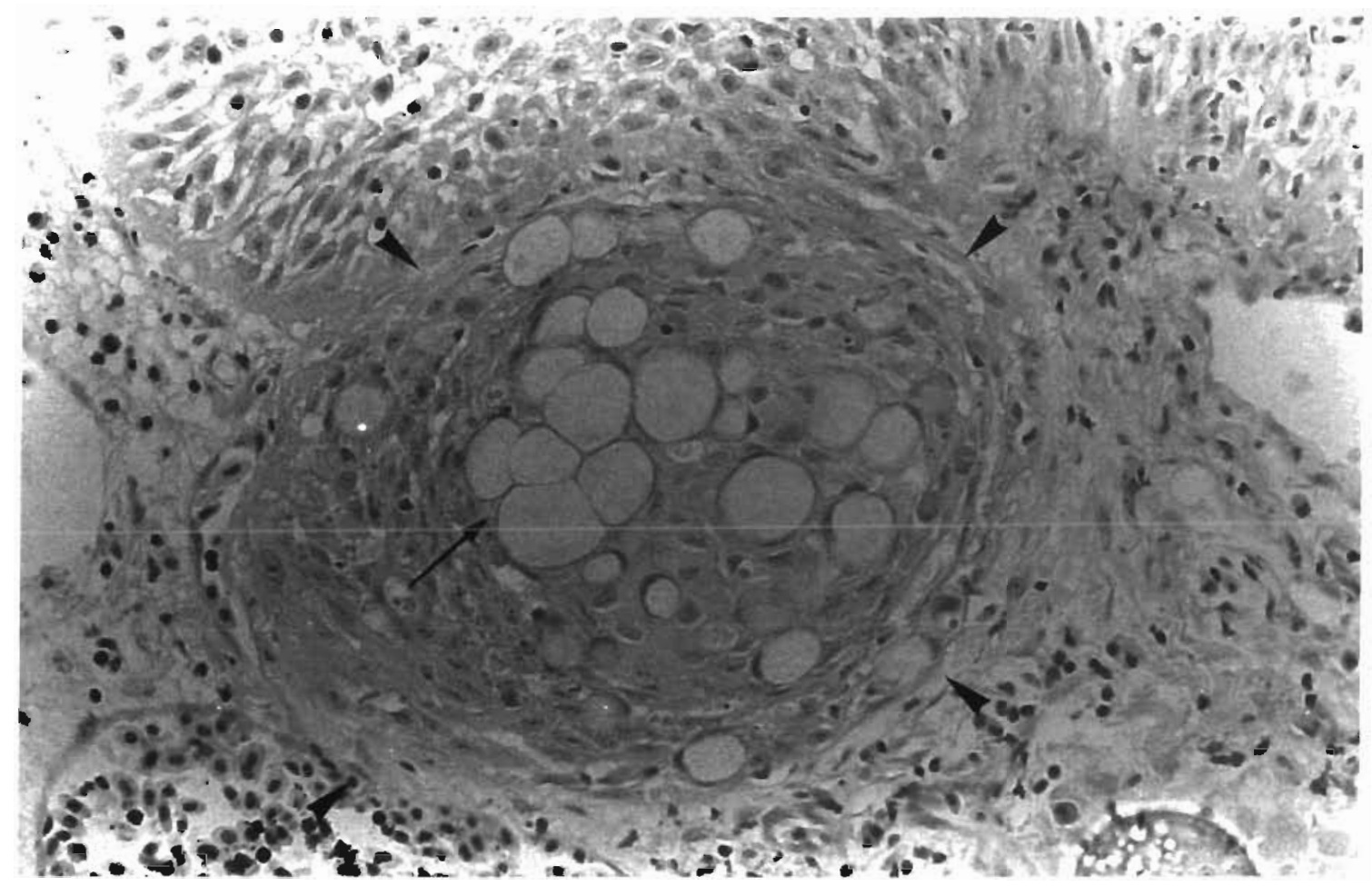

Fig. 2. Barbel, fourth gill arch. Pharyngeal mucous-epithelium. A mucous-epithelial cyst embedded in the propria-submucosa is recognisable (arrowheads) beneath the pharyngeal epithelium. Mucous cell clusters are also evident (arrow). Haematoxylin \& Eosin. Decalcified tissue. $\times 400$ 


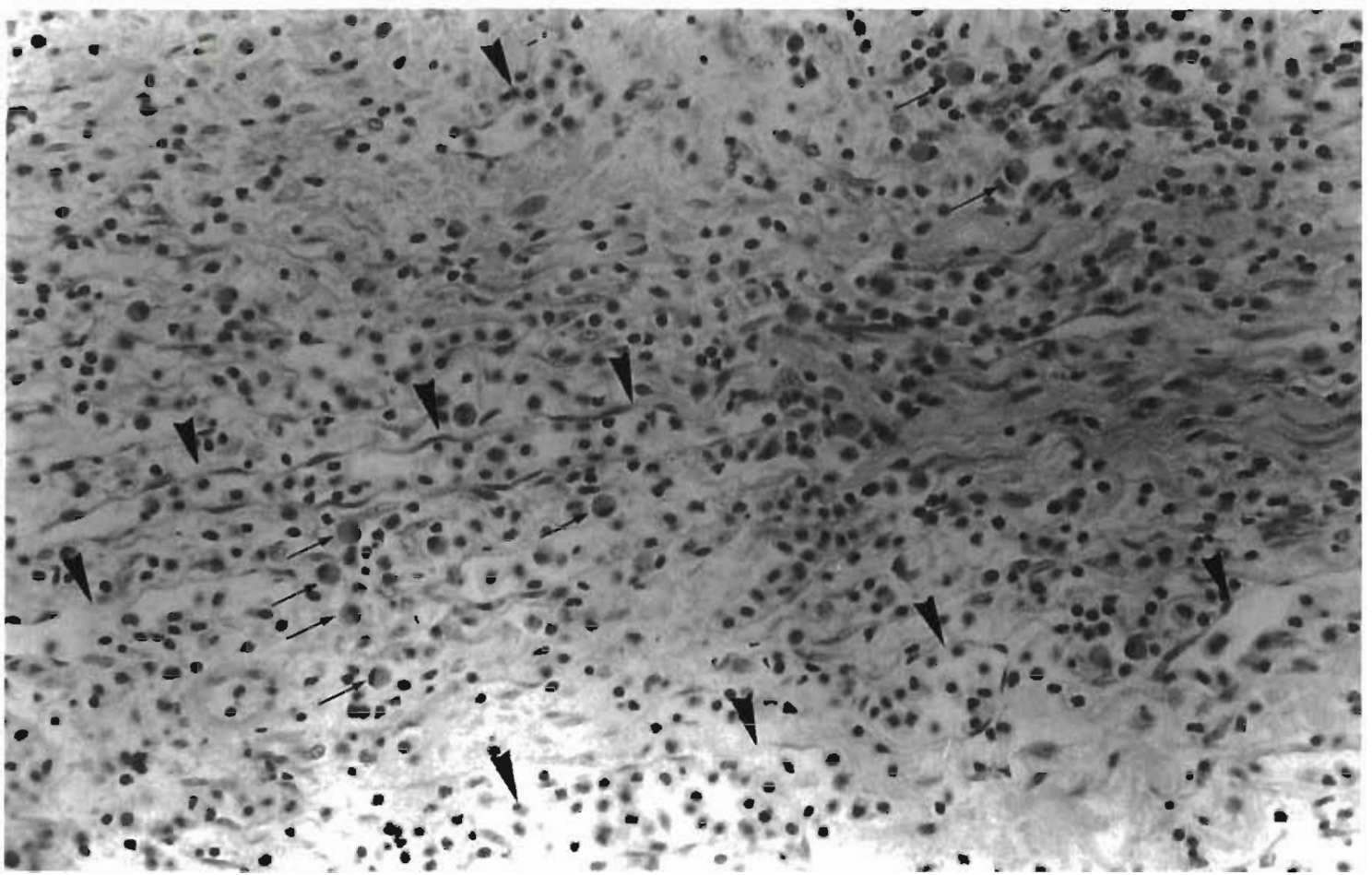

Fig. 3. Barbel, fourth gill arch. Pharyngeal mucosa. The intense inflammatory reaction of the pharyngeal propria-submucosa lining the tumourous mass is apparent. Several blood vessels (arrowheads) and EGCs (arrows) scattered within the tissue are detectable. Haematoxylin \& Eosin. Decalcified tissue. $\times 400$

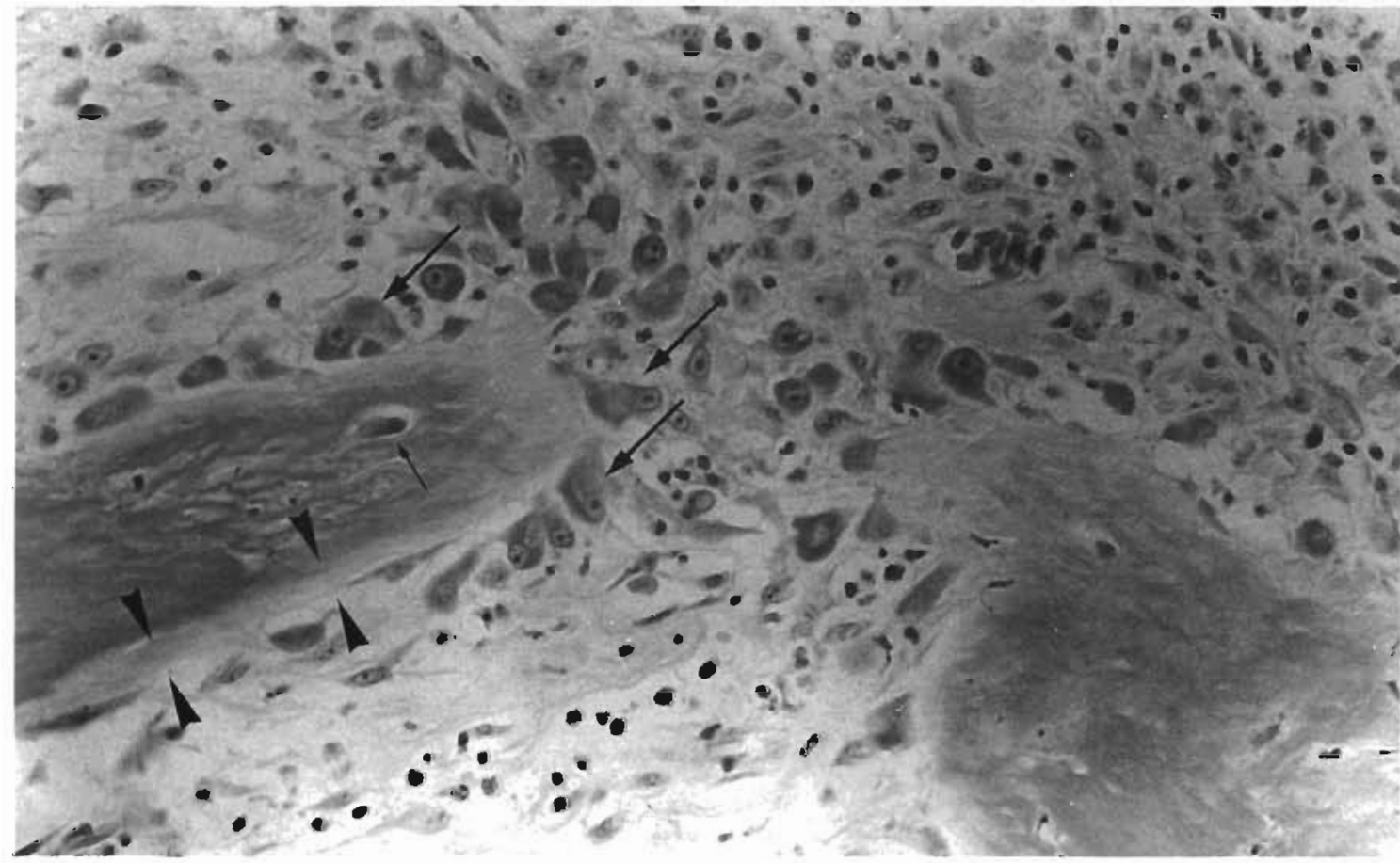

Fig. 4. Barbel, fourth gill arch. Close view of the proliferative edges. Large osteoblasts in palisade formation lining a newly formed bone spicula are visible (large arrows). The portion of osteoid immediately in contact with the osteoblasts appears clearer than the rest, suggesting a maturative progression from osteoid tissue to true osseous tissue (arrowheads). An osteocyte-like cell is apparent embedded within the bone matrix (small arrow). Haematoxylin \& Eosin. Decalcified tissue. $\times 400$ 


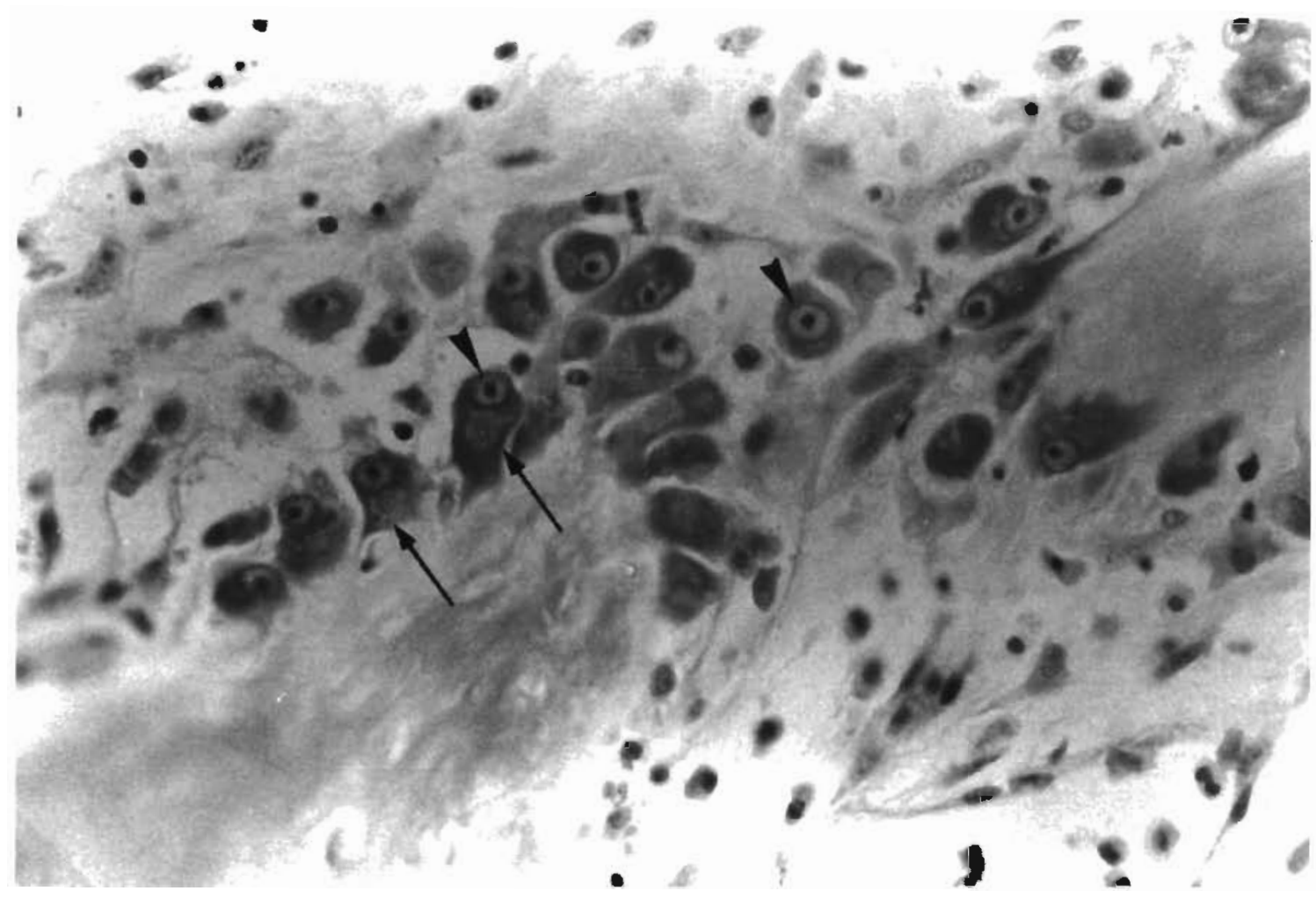

Fig. 5. Barbel, fourth gill arch. Close-up view of osteoblasts in palisade formation lining a bone spicula. A diffuse, transparent, region surrounding the nuclear cytoplasmatic region (arrows), and nuclei rich in euchromatin and prominent nucleoli (arrowheads) are evident within the osteoblasts. Haematoxylin \& Eosin. Decalcified tissue. $\times 600$

suggestive of a high biosynthetic rate. At the proliferative edges, osteoblasts appeared more voluminous and displayed a foamy, clearer, paranuclear portion of the cytoplasm (Fig. 5). Moreover, the portion of osteoid located nearest to the osteoblasts appeared less stainreactive than the rest, suggesting a maturative progression from osteoid tissue to true osseous tissue (Fig. 4). Loose, well-vascularised, fibro-connective tissue was scattered among the trabeculae and lined by fibroblast-like osteoblasts.

At proliferative edges of the tumour, osteoblasts merged into a region of inflammatory fibro-histiocytic tissue embedded in a loose fibro-connective matrix that was rich in lymphocytes, histiocytes and spindleshaped, fibroblast-like cells. Haemorrhages, EGCs and karyorrhectic debris were also detected, suggesting a strong inflammatory and immunological reaction by the fish.

Because the tumour originated from the fish's gill arch, these structures were examined histologically to compare normal and pathological aspects of the tissue. The branchiospines of a normal gill arch had a lamellar axis of spongy bone. Very small, elongate fibroblastlike osteoblasts lined the bone axis and small, sparse osteocytes were embedded in the bone matrix. Normal branchiospines lacked both the palisade-arranged osteoblasts and the proliferative edges found in the previously described tumour bone. The bone lacunae of normal branchiospines were filled with loose, wellvascularised, fibro-connective tissue and EGCs were rare (less than 1 cell per $400 \times$ microscopic field) at the branchiospine base.

The pharyngeal mucous epithelium lining of the tumour mass displayed focal hyperplasias, erosions and ulceration involving the underlying propria-submucosa. Spongiosis and lymphocytic infiltration were also detected; moreover, EGCs were scattered among the mucous epithelium and the propria-submucosa (up to 15 cells per $400 \times$ microscopic field; Fig. 3). Mucous epithelium cysts were embedded in the propria-submucosa and extended into the inflammatory tissue described above (Fig. 2).

Our histopathological observations are consistent with those of an osteogenetic neoplasm (Pool 1990. Palmer 1992, Woodard 1996). The histopathology described here, however, differs with previous descriptions of osteogenetic tumours. In fact, the majority of osteogenetic tumours described in fishes are osteomas, of which only a few-mainly they are osteophytes or reactive osseous hyperplasias - can be 
considered true neoplasms (cf. Wellings 1969, cf. Mawdesley-Thomas 1975, Hayes \& Ferguson 1989). Osteoma itself has been considered by some pathologists to be hamartomas (Aegerter \& Kirkpatrick 1968). According to Pool (1990), these tumours cannot be differentiated from exostosis by microscopic examination. In veterinary medicine, classification, diagnosis and prognosis of osteogenetic neoplasms are accomplished by correlating histopathological patterns with clinical and radiological findings (Pool 1990). The lack of suitable radiological and clinical findings, as well as the lack of a codified histopathological classification for osteogenetic fish neoplasms may explain the problematic and controversial diagnostic findings in fish.

Among vertebrates, teleosts are unique in having 2 major bone types: cellular or osteocytic bone and acellular or anosteocytic bone (Weiss \& Watabe 1979, Ellis et al. 1989). Cellular bone possesses osteocytes embedded within the bone matrix is found in 'ancestrial' teleosts (e.g. Clupeidae, Salmonidae, Cyprinidae) and shares morpho-functional features with the bone tissues of other vertebrates (Weiss \& Watabe 1979, Ellis et al. 1989, Ferguson 1989). By contrast, acellular bone lacks osteocytes, is found only in 'advanced' teleosts (e.g. Percidae and Centrarchidae) and possesses unique morpho-functional features (Moss 1962, 1965, Weiss \& Watabe 1979).

Reviewing the available diagnostic features concerning osteogenetic tumours in domestic animals (Pool 1990, Palmer 1992, Woodard 1996), and based solely on our histopathological examination, we tentatively propose a diagnosis of 'productive osteoblastic osteosarcoma' following the classification reported by Pool (1990). The terms 'productive' and 'osteoblastic' are meant to indicate that the osteosarcoma produces an abundant tumour matrix and is composed of anaplastic osteoblasts. We are led to this diagnosis by (1) the occurrence of osteoblast pleomorphism (i.e. cell morphology ranging from clearly delineated osteoblasts to spindle-shaped, fibroblast-like cells); (2) the lack of a well-developed, complete periosteal demarcation; (3) the presence of eccentric, terminal proliferative edges infiltrating the lining tissues; and (4) the histological evidence that a strong inflammatory, and possibly immunological, reaction occurred.

Concerning the inflammatory response and EGCs, the role of the latter in normal and pathological fish tissue is still a matter of debate, although recent experimental surveys suggest a homology with mammalian mastocytes (Reite \& Evensen 1994, Reite 1997). Mammalian mast cells are involved in acute inflammation, in cellular growth modulation, and in leukocyte differentiation and activation (Aloe \& Levi-Montalcini 1977. Norrby 1983, Wodnar-Filipowicz et al.
1989, Katayama et al. 1992, Leon et al. 1994, Paus et al. 1994, Galli \& Costa 1995, Galli 1997). The ability of mammal mast cells to synthesise and release Tumour Necrosis Factor (TNF) is particularly interesting (Gordon \& Galli 1991). In humans TNF is known to modulate a variety of physiological and pathological events such as: inflammation (acute phase reaction, endothelial effects, fibroblast effects, leukocyte effects), delayed hypersensitivity (endothelial effects), cell proliferation and tissue regeneration (mitogenic for hepatocytes and other cells), apoptosis (TNF receptor TNFR1 - activation), and food intake control (tumour cachexia, obesity; cf. Cotran et al. 1999). Unfortunately, apart from the involvement of fish EGCs/mast cells in the inflammatory reaction (Secombes 1996, Reite 1997, 1998), there is no corresponding information about their role in fish tissues. Hence, the abundance of EGCs within the tumour mass, particularily at the proliferative edges and the inflammatory interface, must be tentatively interpreted in light of mammalian mast cell function and the apparent homology shared by fish EGCs and the latter. Similarly, the abundance of EGCs in the pharyngeal mucous epithelium and propria-submucosa can presumably be related to the epithelial modifications (mainly hyperplasia) and to epithelial cyst formation observed by means of extrapolation from mammalian mast cell action. Regarding cytochines in fish, although TNF has been reported in rainbow trout macrophages by Zelikoff et al. (1990) and in the serum of virusinfected fish by Ahne (1993), their detection and evaluation of function has just begun. Thus, the existence of TNF is rarely determined by identification at cDNA level, rather TNF is detected by the cross reaction with antibodies against mammalian cytochines and by the biological cross reactivity with mammalian cytochines (cf. Manning \& Nakanishi 1996).

Although osteogenetic tumours are well known and described in fish oncology, they have not been reported to affect gills (cf. Wellings 1969, cf. Mawdesley-Thomas 1975). Considering the exposure gills have to the environment, and the probability that they will encounter carcinogens, it is surprising that the incidence of neoplasm in fish gills is so low compared other tissues and organs (cf. Wellings 1969, cf. Mawdesley-Thomas 1975, cf. Roberts 1989). To the best of our knowledge, and in view of the available literature on fish tumours (Wellings 1969, MawdesleyThomas 1975), this is the first description of a osteogenetic neoplasm affecting barbel gills.

Acknowledgements. The authors are grateful to Dr Todd Wellnitz of the Department of Biology at Colorado State University for the correction and improvement of the English of the final draft of this manuscript. 


\section{LITERATURE CITED}

Aegerter E, Kirkpatrick JA (1968) Orthopedic diseases. WB Saunders Company, Philadelphia

Ahne W (1993) Presence of interleukins (IL-1, IL-3, IL-6) and the tumour necrosis factor (TNF alpha) in fish sera. Bull Eur Assoc Fish Pathol 13:106-107

Aloe L, Levi-Montalcini R (1977) Mast cells increase in tissues of neonatal rats injected with the nerve growth factor. Brain Res 133:358-366

Cotran RS, Kumar V, Collins T (1999) Robbins pathological basis of disease. WB Saunders Company, Philadelphia

Ellis AE, Roberts RJ, Tytler P (1989) Anatomy and physiology of teleosts. In: Roberts RJ (ed) Fish pathology. Baillière Tindall, London, p 13-55

Ferguson HW (1989) Musculoskeletal system. In: Ferguson (ed) Systemic pathology of fishes. Iowa State University Press, Ames, p 215-229

Galli SJ (1997) The mast cell: a versatile effector cell for a challenging world. Int Arch Allergy Appl Immunol 113: $14-22$

Galli SJ, Costa JJ (1995) Mast cell-leukocyte cytokine cascades in allergic inflammation. Allergy 50(11):851-862

Gordon JR, Galli SJ (1991) Release of both performed and newly synthesised Tumour Necrosis Factor (TNF-alpha) cachetin by mouse mast cells stimulated via the FcRI. A mechanism for the sustained action of mast cell-derived TNF-alpha during IgE-dependent biological responses. J Exp Med 174:103-107

Hayes MA, Ferguson HW (1989) Neoplasia in fish. In: Ferguson (ed) Systemic pathology of fishes. Iowa State University Press, Ames, p 230-247

Katayama I, Yokozeki H. Nishioka K (1992) Mast cell-derived mediators induce epidermal cell proliferation: clue for lichenified skin lesion formation in atopic dermatitis. Int Arch Allergy Appl Immunol 98:410-414

Leon A, Buriani A, Dal Toso R, Fabris M, Romanello S, Aloe L, Levi-Montaicini R (1994) Mast cells synthesise, store and release Nerve Growth Factor. Proc Natl Acad Sci 91(9): $3739-3743$

Manning MJ, Nakanishi T (1996) The specific immune system: cellular defenses. In: Iwama G, Nakanishi T (eds) The fish immune system. Hoar WS, Randall DJ, Farrell A.P (eds) Fish physiology series, Vol 15. Academic Press, San Diego, p 159-205

Mawdesley-Thomas LE (1975) Neoplasia in fish. In: Ribelin WE, Migaki G (eds) Pathology of fishes. The University of Wisconsin Press, Madison, p 805-870

Mazzi V (1977) Manuale di tecniche istologiche e istochimiche. Piccin Editore, Padova

McManus JFA, Mowry RW (1960) Staining methods. Histologic and histochemical. Paul B Hoeber Inc., Medical Division of Harper, Brothers, New York

Moss ML (1962) Studies of the acellular bone of teleost fish. 2.

Editorial responsibility: Nicolaus Peters,

Hamburg, Germany
Response to fracture under normal and acalcemic variations. Acta Anat 48:46-60

Moss ML (1965) Studies of the acellular bone of teleost fish. 5 Histology and mineral homeostasis of fresh water species. Acta Anat 60:262-276

Norrby K (1983) Intradermal mast cells secretion causing cutaneous mitogenesis. Virchows Arch 42:263-269

Palmer N (1992) Bones and joints. In: Jubb KVF, Kennedy PC Palmer N (eds) Pathology of domestic animals, Vol I. Academic Press, San Diego, p 1-181

Paus R, Luftl M, Czarnetzki BM (1994) Nerve Growth Factor modulates keratinocyte proliferation in murine skin organ colture. Br J Dermatology 130:174-180

Pearse AGE (1985) Pigments and pigment precursors. In Pearse AGE (ed) Histochemistry. Theoretical and applied Vol II. Churchill Livingstone, Edinburgh, p 874-928

Pool RR (1990) Tumors of bone and cartilage. In: Moulton JE (ed) Tumors in domestic animals. University of California Press, Berkely, p 157-230

Reite OB (1997) Mast cells/eosinophilic granule cells of salmonids: staining properties and responses to noxious agents. Fish Shellfish Immunol 7:567-584

Reite OB (1998) Mast cells/eosinophile granule cells of teleostean fish: a review focusing on staining properties and functional responses. Fish Shellfish Immunol 8:489-513

Reite OB, Evensen $\varnothing$ (1994) Mast cells in the swimbladder of Atlantic salmon Salmo salar. histochemistry and responses to compound $48 / 80$ and formalin-inactivated Aeromonas salmonicida. Dis Aquat Org 20:95-100

Roberts RJ (1989) Neoplasia of teleosts. In: Roberts RJ (ed) Fish pathology. Baillière Tindall, London, p 153-172

Secombes CJ (1996) The nonspecific immune system: cellular defenses. In: Iwama G, Nakanishi T (eds) The fish immune systern. Hoar WS, Randall DJ, Farrell AP (eds) Fish physiology series, Vol 15. Academic Press, San Diego, p 63-103

Weiss RE, Watabe $N$ (1979) Studies on the biology of fish bone. III. Ultrastructure of osteogenesis and resorption in osteocytic (cellular) and anosteocytic (acellular) bones. Calcif Tissue Int 28:43-56

Wellings SR (1969) Neoplasia and primitive vertebrate phylogeny: echinoderms, prevertebrates, and fishes - a review. Natl Cancer Inst Monogr 31:59-128

Wodnar-Filipowicz A, Heusser CH, Moroni C (1989) Production of the haemopoietic growth factor GM-CSF and interleukin-3 by mast cells in response to IgE receptor-mediated activation. Nature 339:150-151

Woodard JC (1996) Skeletal system. In: Jones TC, Hunt RD, King NW (eds) Veterinary pathology. Williams \& Wilkins, Baltimore, p 899-946

Zelikoff JT, Enane NA, Bowser D, Squibb KS (1990) Fish macrophage 1: development of a system for detecting immunomodulating effects of environmental pollutants. Symposium at the Society of Environmental Toxicology and Chemistry, 11 th Annual Meeting, Arlington, p 86

Submitted: March 29, 1999; Accepted: June 17, 1999

Proofs received from author(s): August 13, 1999 